Supporting information

\title{
Detection of thiol functionality and disulfide bond formation
}

\section{by polyoxometalate}

Hiroyuki Konno, * Haruto Yasumiishi, Reika Aoki, Ikumi Nitanai, Shigekazu Yano

Department of Biological Engineering, Graduate School of Science and Engineering, Yamagata University, Yonezawa, Yamagata 992-8510, Japan

*Corresponding author

E-mail: konno@yz.yamagata-u.ac.jp

TEL\&FAX:+81-238-26-3131 
After $10 \mathrm{~min}$

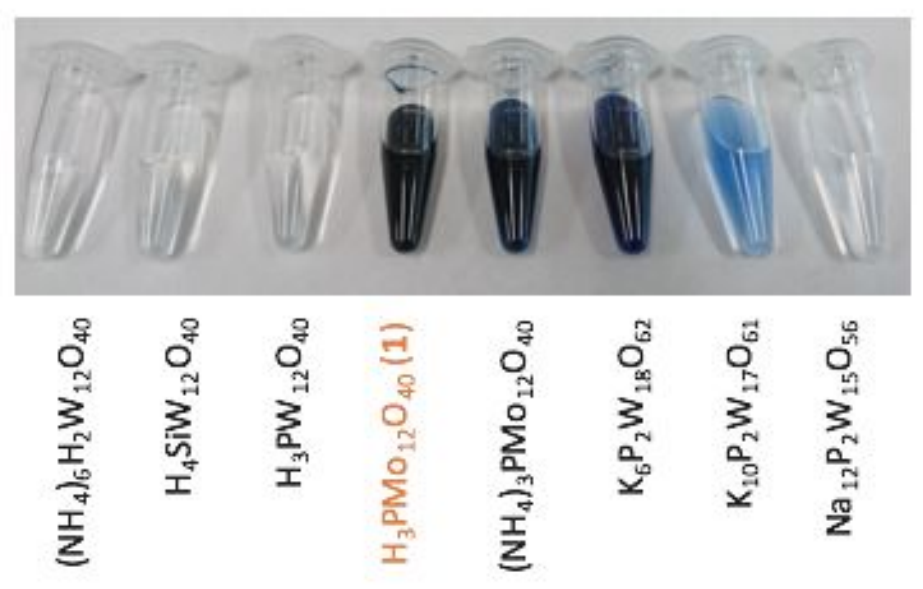

Figure S1. The each reaction tube of L-cysteine and POMs. 


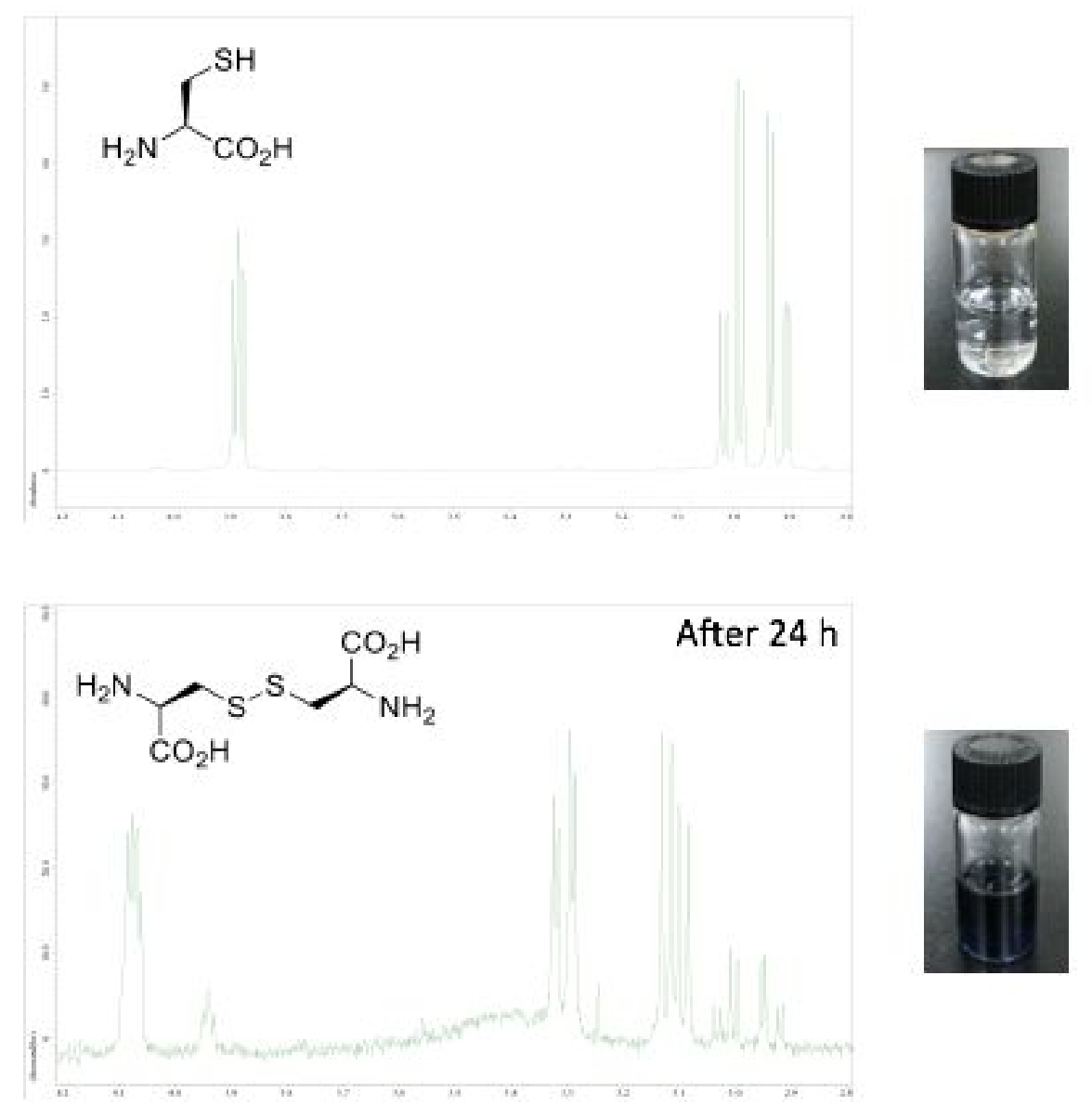

Figure S2. ${ }^{1} \mathrm{H}-\mathrm{NMR}$ spectra of L-cysteine and POM mixture $\left(500 \mathrm{MHz}, \mathrm{D}_{2} \mathrm{O}\right)$.

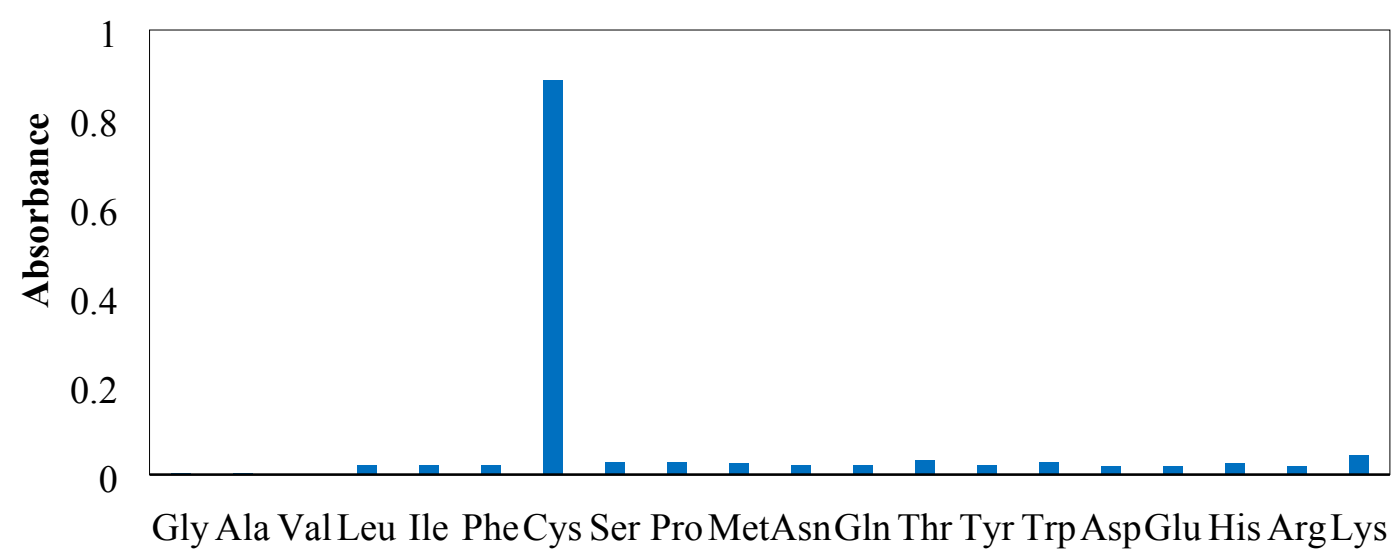


Figure S3. Absorbance of each reaction tube of 20 proteinogenic amino acids and POMs (700 nm).

A.

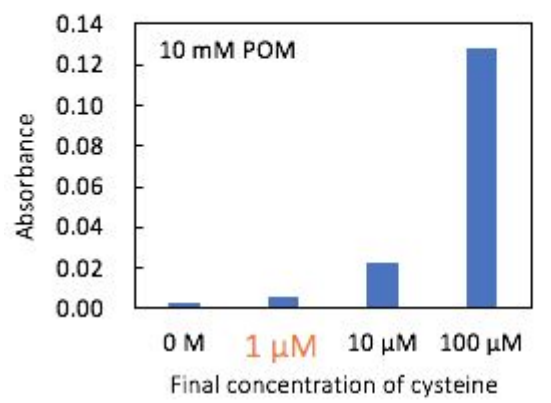

C.

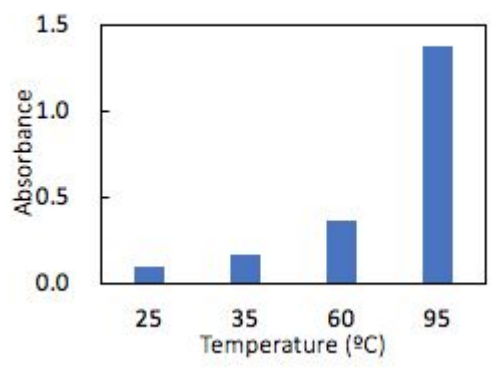

B.

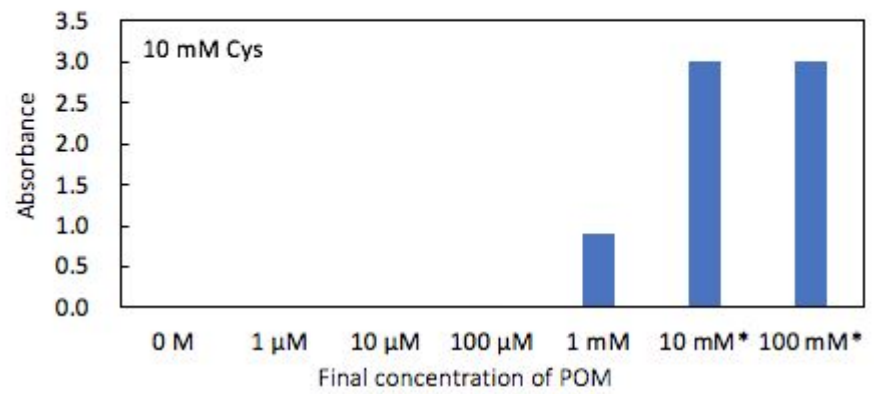

D.

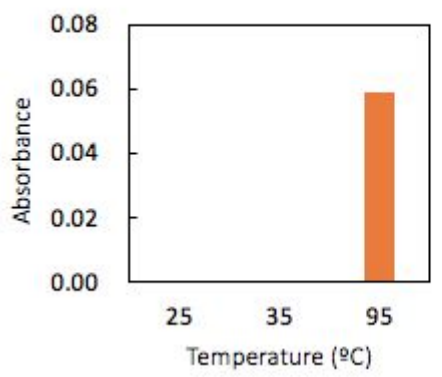

Figure S4. (A) Detection limit of cysteine. (B) Relationship of absorbance. (C) Relationship of absorbance and reaction temperature. (D) Absorbance of POM solutions at 25,35 , and $95^{\circ} \mathrm{C}$. 


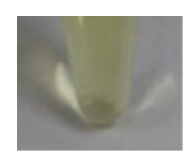

$\mathrm{H}_{2} \mathrm{O}$

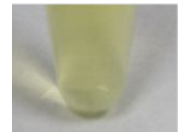

AcOEt

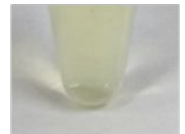

$\mathrm{MeOH}$

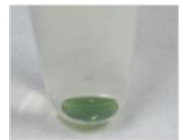

ether

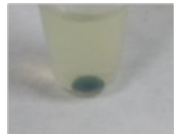

$\mathrm{CH}_{2} \mathrm{Cl}_{2}$

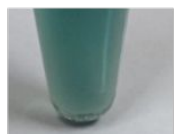

DMF

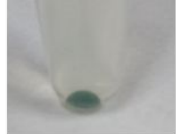

$\mathrm{CHCl}_{3}$

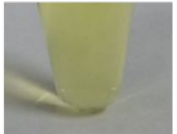

$\mathrm{CH}_{3} \mathrm{CN}$

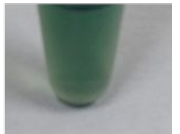

THF

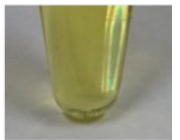

DMSO

Figure S5. Optimization of solvents for the oxidative disulfide bond formation.

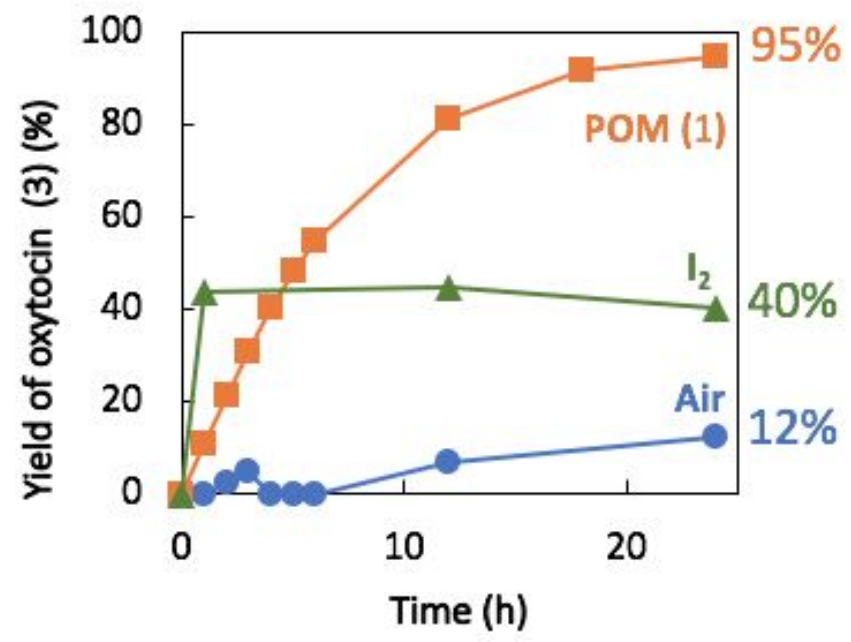

Figure S6. Generation rates of oxytocin (3) by respective methods. Yields were calculated on HPLC $(\mathrm{UV}=220 \mathrm{~nm})$. 

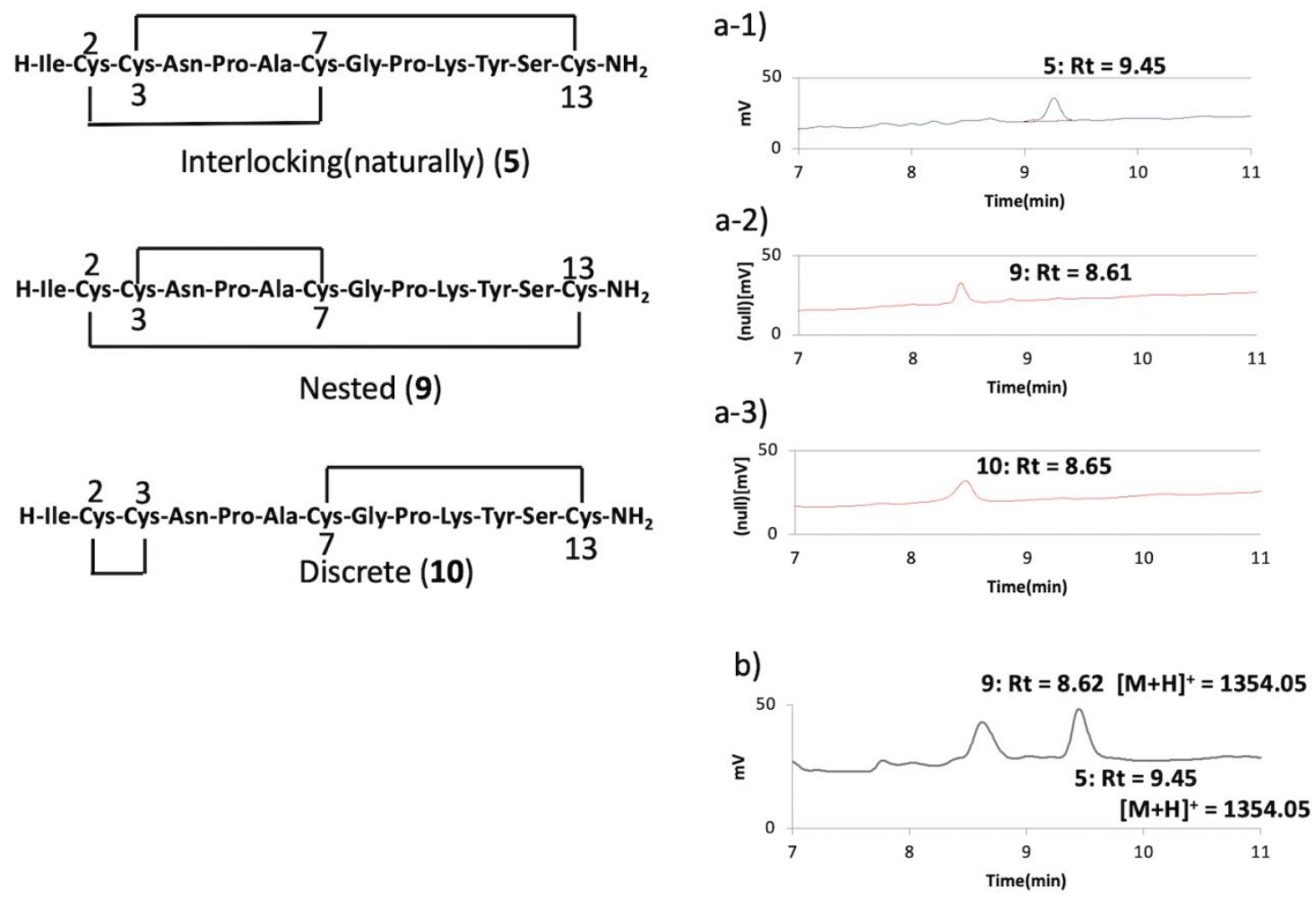

Figure S7. a) HPLC profile of three conotoxins (UV = $220 \mathrm{~nm}$ ) prepared independently by us. a-1) "interlocking" conotoxin SI (5), a-2) "nested" conotoxin SI (9), a-3) “discrete" conotoxin SI (10). b) HPLC profile of conotoxicin SI (5 and 9) derived from POM treatment. Linear gradient starting from 10 to $90 \% \mathrm{CH}_{3} \mathrm{CN}$ in $0.1 \%$ aqueous TFA over $30 \mathrm{~min}$ at a flow rate of $1.0 \mathrm{~mL} / \mathrm{min}$, and detection at $220 \mathrm{~nm}$. 


\begin{tabular}{|c|c|c|c|}
\hline type & linear & monocyclic & Conotoxin $\mathrm{SI}$ \\
\hline interlocking & $\begin{array}{c}\mathrm{Rt}=8.60 \\
{[\mathrm{M}+\mathrm{H}]^{+}=1500.37}\end{array}$ & $\begin{array}{c}\mathrm{Rt}=7.92 \\
{[\mathrm{M}+\mathrm{H}]^{+}=1498.41}\end{array}$ & $\begin{array}{c}\mathrm{Rt}=9.45 \\
{[\mathrm{M}+\mathrm{H}]^{+}=1354.34}\end{array}$ \\
\hline nested & $\begin{array}{c}\mathrm{Rt}=8.24 \\
{[\mathrm{M}+\mathrm{H}]^{+}=1500.37}\end{array}$ & $\begin{array}{c}\mathrm{Rt}=7.96 \\
{[\mathrm{M}+\mathrm{H}]^{+}=1498.39}\end{array}$ & $\begin{array}{c}\mathrm{Rt}=8.61 \\
{[\mathrm{M}+\mathrm{H}]^{+}=1354.33}\end{array}$ \\
\hline discrete & $\begin{array}{c}\mathrm{Rt}=8.26 \\
{[\mathrm{M}+\mathrm{H}]^{+}=1500.37}\end{array}$ & $\begin{array}{c}\mathrm{Rt}=7.79 \\
{[\mathrm{M}+\mathrm{H}]^{+}=1498.39}\end{array}$ & $\begin{array}{c}\mathrm{Rt}=8.65 \\
{[\mathrm{M}+\mathrm{H}]^{+}=1354.36}\end{array}$ \\
\hline
\end{tabular}

Figure S8. Retention time (Rt) of HPLC profile and ESI-MS analysis for preparation of three conotoxin SIs. Linear gradient starting from 10 to $90 \% \mathrm{CH}_{3} \mathrm{CN}$ in $0.1 \%$ aqueous TFA over $30 \mathrm{~min}$ at a flow rate of $1.0 \mathrm{~mL} / \mathrm{min}$, and detection at $220 \mathrm{~nm}$. Linear peptide with two Acm protecting groups: ESI-MS $m / z[\mathrm{M}+\mathrm{H}]^{+}$: Calcd. For $\mathrm{C}_{61} \mathrm{H}_{97} \mathrm{~N}_{17} \mathrm{O}_{19} \mathrm{~S}_{4}$ : 1500.61. Monocyclic peptide with two Acm protecting groups: ESI-MS $m / z[\mathrm{M}+\mathrm{H}]^{+}$: Calcd. For $\mathrm{C}_{61} \mathrm{H}_{95} \mathrm{~N}_{17} \mathrm{O}_{19} \mathrm{~S}_{4}:$ 1498.59. Conotoxin SI: ESI-MS $m / z[\mathrm{M}+\mathrm{H}]^{+}$: Calcd. For $\mathrm{C}_{55} \mathrm{H}_{83} \mathrm{~N}_{15} \mathrm{O}_{17} \mathrm{~S}_{4}$ : 1354.5052 . 


\section{Experimental}

General. All solvents were reagent grade. All commercial reagents were of the highest purity available. ${ }^{1} \mathrm{H}(400$ and $500 \mathrm{MHz})$ and ${ }^{13} \mathrm{C}$ NMR (100 and $125 \mathrm{MHz}$ ) were determined on a JNM-ECX400 and JNM-ECX500. Chemical shifts are reported in ppm with reference to tetramethylsilane [ ${ }^{1} \mathrm{H}$ NMR: TMS (0.00)], or solvent signals $\left[{ }^{1} \mathrm{H}\right.$ NMR: $\mathrm{CDCl}_{3}$ (7.26), $\mathrm{MeOH}-\mathrm{d}_{4}$ (3.30); ${ }^{13} \mathrm{C} \mathrm{NMR:} \mathrm{CDCl}_{3}$ (77.16), $\mathrm{MeOH}-\mathrm{d}_{4}$ (50.05)]. Mass spectra were recorded on a JEOL AccuTOF JMS-T100LC (ESI). Analytical HPLC was carried out with a COSMOSIL $5 \mathrm{C}_{18}$-AR-II column $(4.6 \mathrm{ID} \times 150 \mathrm{~mm})$ with a linear gradient of $\mathrm{MeCN}\left(0.1 \%\right.$ TFA) in $\mathrm{H}_{2} \mathrm{O}(0.1 \%$ TFA) at a run time of $30 \mathrm{~min}$ (flow rate of $1 \mathrm{~mL} / \mathrm{min}$ ), on a SHIMADZU SPD-10A as a UV-Vis detector, HITACHI L-6000 Pump and HITACHI L-6200 Intelligent Pump. Preparative HPLC was performed with a COSMOSIL $5 \mathrm{C}_{18}$-AR-II column $(10 \mathrm{ID} \times 250 \mathrm{~mm})$ with a linear gradient of $\mathrm{MeCN}(0.1 \%$ TFA) in $\mathrm{H}_{2} \mathrm{O}(0.1 \% \mathrm{TFA})$ at a run time of $30 \mathrm{~min}$ (flow rate of $2 \mathrm{~mL} / \mathrm{min}$ ), on a SHIMADZU SPD-10A $i$ as a UV-Vis detector and HITACHI L-6200 Intelligent Pump. UV measurements were recorded at a wavelength of $220 \mathrm{~nm}$ for the peptide analyses. Absorbance was measured with the HITACHI U-1900.

General methods for peptide synthesis using rink amide resin. Rink amide resin (100 $\mathrm{mg}, 56 \mu \mathrm{mol})$ was swelled in DMF $(2 \mathrm{~mL})$ for $30 \mathrm{~min}$ followed by Fmoc-deprotection with $20 \%$ piperidine/DMF ( $2 \mathrm{~mL}$ ) for $30 \mathrm{~min}$. The resin was washed with DMF. Standard Fmoc-SPPS protocols were employed: 1) Fmoc-AA-OH (3 equiv., $168 \mu \mathrm{mol}$ ) and coupling reagents (DIPCI/HOBt/DIPEA, 3 equiv., $168 \mu \mathrm{mol}$ ) were dissolved in DMF (2 
$\mathrm{mL}$ ), and the mixture added to the resin and mixed for each reaction time. 2) The solvent was removed by filtration and the resin was washed with DMF (2 mL x 3). 3) The Fmoc group of the resin was removed with $20 \%$ piperidine/DMF $(2 \mathrm{~mL})$ for each reaction time.

4) The solvent was removed by filtration and the resin was washed with DMF ( $2 \mathrm{~mL} x$

$3)$. This coupling/deprotection cycle was carried out until completion of the synthesis.

General methods for isolation of peptides. After the SPPS, the product was cleaved from the resin using TFA/TIPS/ $\mathrm{H}_{2} \mathrm{O}(5 \mathrm{ml}, 95: 2.5: 2.5)$. The mixture was filtered and evaporated under reduced pressure. To the residue in $\mathrm{Et}_{2} \mathrm{O}$ was centrifuged $(7000 \mathrm{rpm} \mathrm{x}$ $10 \mathrm{~min}, 4^{\circ} \mathrm{C}$ ) and decanted. The crude product was purified with RP-HPLC and lyophilized to afford designed peptide as a white powder. Oxytocin (H-Cys-Tyr-Ile-GlnAsn-Cys-Pro-Leu-Gly-NH ${ }_{2}$ ): ESI-MS $m / z[\mathrm{M}+\mathrm{H}]^{+}$: Calcd. For $\mathrm{C}_{43} \mathrm{H}_{69} \mathrm{~N}_{12} \mathrm{O}_{12} \mathrm{~S}_{2}:$ 1009.46, Found: 1009.44. Bactenecin (H-Arg-Leu-Cys-Arg-Ile-Val-Val-Ile-Arg-Val-Cys-Arg$\mathrm{OH})$ : ESI-MS $m / z[\mathrm{M}+\mathrm{H}]^{+}$: Calcd. For $\mathrm{C}_{63} \mathrm{H}_{122} \mathrm{~N}_{24} \mathrm{O}_{13} \mathrm{~S}_{2}$ : 1485.90, Found: 1485.74. $\alpha-$ conotoxin SI (H-Ile-Cys-Cys-Asn-Pro-Ala-Cys-Gly-Pro-Lys-Tyr-Ser-Cys-OH): ESI-MS $m / z[\mathrm{M}+\mathrm{H}]^{+}$: Calcd. For $\mathrm{C}_{55} \mathrm{H}_{88} \mathrm{~N}_{16} \mathrm{O}_{16} \mathrm{~S}_{4}$ : 1358.54, Found: 1358.22.

Detection of cysteine by POM. To a solution of L-cysteine (5 mg) in $\mathrm{H}_{2} \mathrm{O}(500 \mu \mathrm{L})$ was added POM $(100 \mu \mathrm{L}, 10 \mathrm{mg} / \mathrm{mL})$ at room temperature. After $24 \mathrm{~h}$, absorbance was measured at $700 \mathrm{~nm}$.

Detection of amino acid by POM. To a solution of amino acid $(1 \mathrm{mg})$ in $\mathrm{H}_{2} \mathrm{O}(100 \mu \mathrm{L})$ was added POM $(20 \mu \mathrm{L}, 10 \mathrm{mg} / \mathrm{mL})$ at room temperature. After $10 \mathrm{~min}$, absorbance was measured at $880 \mathrm{~nm}$.

Detection of GSH by POM. To a solution of GSH $(3.1 \mathrm{mg})$ in $\mathrm{H}_{2} \mathrm{O}(1 \mathrm{~mL})$ was added POM ( $1.8 \mathrm{mg}, 1 \mu \mathrm{mol})$ at room temperature. After $24 \mathrm{~h}$, the mixture was applied to HPLC ( $\left.1 \mathrm{~mL} / \mathrm{min}, 0-30 \mathrm{~min}, 0-30 \% \mathrm{CH}_{3} \mathrm{CN} / \mathrm{H}_{2} \mathrm{O}\right)$ and $\mathrm{GSSG}$ was detected $(\mathrm{Rt}=9.8 \mathrm{~min})$. ESIMS $m / z[\mathrm{M}+\mathrm{H}]^{+}$: Calcd. For $\mathrm{C}_{20} \mathrm{H}_{33} \mathrm{~N}_{6} \mathrm{O}_{12} \mathrm{~S}_{2}$ : 613.16, Found: 613.09

Synthesis of oxytocin (3) by disulfide bond formation. To a solution of linear oxytocin $7(2 \mathrm{mg}, 2.0 \mu \mathrm{mol})$ in DMSO $(100 \mu \mathrm{L})$ was added POM $(1.8 \mathrm{mg}, 1.0 \mu \mathrm{mol})$ at room temperature. After $24 \mathrm{~h}$, the mixture was purified by HPLC to give oxytocin $3(1.8 \mathrm{mg}$, $1.8 \mu \mathrm{mol}, 90 \%)$ as a white powder. ESI-MS $m / z[\mathrm{M}+\mathrm{H}]^{+}$: Calcd. For $\mathrm{C}_{43} \mathrm{H}_{67} \mathrm{~N}_{12} \mathrm{O}_{12} \mathrm{~S}_{2}$ : 1007.44, Found: 1007.29. 
Synthesis of bactencin (4) by disulfide bond formation. To a solution of linear bactencin $8(1.5 \mathrm{mg}, 1.0 \mu \mathrm{mol})$ in $0.1 \mathrm{M} \mathrm{HCl} / \mathrm{DMSO}(2: 1,300 \mu \mathrm{L})$ was added POM $(1.8$ $\mathrm{mg}, 1.0 \mu \mathrm{mol}$ ) at room temperature. After $24 \mathrm{~h}$, the mixture was purified by HPLC to give bactencin 4 (1.2 mg, $0.8 \mu \mathrm{mol}, 80 \%)$ as a white powder. ESI-MS $m / z[\mathrm{M}+\mathrm{H}]^{+}$: Calcd. For $\mathrm{C}_{63} \mathrm{H}_{120} \mathrm{~N}_{24} \mathrm{O}_{13} \mathrm{~S}_{2}: 1483.88$, Found:1483.61. 